\title{
Security Sector Reform, Small Arms and Light Weapons and Gender in the Post-Conflict Western Balkans
}

\author{
Eszter Szedlacsek ${ }^{1}$
}

\begin{abstract}
We all experience war in a different way - building peace in post-conflict environments requires solutions that bring together various aspects of these experiences at the local, national and international levels. However, the actors involved and the social groups they address are only rarely those at the margin, and the diversity of the catch-all category of "locals" frequently goes unacknowledged when considering Security Sector Reform (SSR) and especially small arms ${ }^{2}$ control. Numerous studies have focused on SSR and gender in the Balkans, on perceptions of security in post-conflict environments and its gender-related aspects, as well as on the gendered aspects of small arms, but so far the analysis bringing together all of these aspects is scarce. This paper aims to address this gap, providing an overview of these areas to show that attempts at state-building and security-provision in the Western Balkans have failed to appropriately incorporate gender mainstreaming into their agendas. It is the central claim of this paper that policymakers must realize that gender mainstreaming without a broader understanding of gendered aspects of security does not and will not have transformative power - neither in the Western Balkans, nor in other post-conflict environments.
\end{abstract}

\footnotetext{
${ }^{1}$ Eszter Szedlacsek is a Postgraduate Public Policy student at Central European University (CEU) and University of York (UK). She has formerly been affiliated with the Global Public Policy Institute (GPPi) and the European Parliament. Her main areas of research include operations in post-conflict environments, gender, security sector reform, and EU security policy.

2 There is no generally agreed upon definition of small arms and light weapons. The hereby used understanding of SALW relies therefore on the Small Arms Survey's definition (2008). Small arms include revolvers and self-loading pistols, rifles and carbines, assault rifles, sub-machine guns and light-machine guns. Light weapons refer to heavy machine guns, hand-held under-barrel and mounted grenade launchers, portable launchers of anti-tank missile and rocket systems; portable launchers of anti-aircraft missile systems and mortars of calibres of less than $100 \mathrm{~mm}$. Throughout the paper, the term 'small arms' may refer to small arms and light weapons and is used synonymously to the term 'firearms' (though the latter usually comprises small arms and heavy machine guns).
} 
doi: 10.14267/cojourn.2019v4n1a4

Keywords: Security Sector Reform (SSR), post-conflict, small arms and light weapons (SALW), gender, Western Balkans

\section{Introduction and Conceptual Background}

In the aftermath of UN Security Resolution 1325 (2000) on women, peace and security frequently referred to as 'the' resolution on the role of gender in post-conflict settings a growing number of liberal and critical feminist works have emerged on the topic gender and SSR in post-conflict environments (Willett 2010; Shepherd 2011; Porter 2003; Myrttinen, Khattab, and Naujoks 2017; Mobekk 2010; MacKenzie 2009; Krause, Krause, and Bränfors 2018; Jenichen, Joachim, and Schneiker 2018; Huber and Hudson 2019; Holvikivi 2015; Gibbings 2011; Ellerby 2013; Gordon 2019). Recently, a number of scholars have focused on linking gender and SSR in the Western Balkan context by directing attention to the relationship between local ownership and gender (Gordon 2014; Ansorg and Gordon 2019; Gordon 2015; McLeod 2015), to international gender policies (Pupavac 2010) and masculinities (Munn 2008; Baliqi 2018; Farquet 2018). However, researchers' central inquiries are usually based on approaches to internationally supported SSR missions which do not mainstream gender in their approach (Triantafyllou 2018; Skendaj et al. 2019; Simangan 2018; Heinemann-Grüder and Grebenschikov 2006; Greiçevci 2011; Gajić 2017; Dursun-Ozkanca and Crossley-Frolick 2012). Therefore, there is a significant gap in scholarly research on post-conflict masculinities, femininities and gendered aspects of post-war reconstruction since the time when the mainstreaming of gender became more common, especially with respect to the Balkan region. ${ }^{3}$

As concepts may carry different meanings even in the same academic circles, it is necessary to outline what is meant by 'gender', 'women' and 'SSR'. The security and defence sector mainly consists of traditional security actors, such as policymakers, border guards, justice institutions. SSR's main aim is to transform this security sector into a politically accountable, stable and transparent democratic security system ${ }^{4}$ (OECD, 2008).

\footnotetext{
${ }^{3}$ In this research paper, the terms 'Balkans', 'Western Balkans' and 'South-East Europe (SEE)' are used with reference to the countries and entities emerging after the dissolution of Yugoslavia. The term 'Balkans' carries negative connotations in some contexts, but here it is used in a neutral descriptive sense. It may also be noted that the above-mentioned terms are at times used to cover, beyond the former Yugoslavia, also Bulgaria, Serbia, Bosnia-Herzegovina, Albania, Croatia, Kosovo and North Macedonia, reference to Kosovo here being understood with reference to Security Council resolution 1244 (1999).

${ }^{4}$ In the OECD Handbook on SSR (2008), SSR is defined as "transforming the security sector/system, which includes all the actors, their roles, responsibilities and actions, so that they work together to manage and
} 
doi: 10.14267/cojourn.2019v4n1a4

More often than not, external international actors who engage in post-conflict reconfiguration have interests significantly different from those of the local political elite that in turn may not represent the needs of the local population (Mobekk 2010). Following this line of thought, most SSR practitioners agree that security sector reform is most efficient and sustainable if local political actors and authorities take full ownership of the process. Theoretically, the local population urges local actors to engage in reform. In practice, the concept of local ownership presents major challenges (Gordon 2014, 2015; Skendaj et al. 2019).

Embracing the gender aspect has regained attention in the early $21^{\text {st }}$ century. Following the UN Secretary-General's definition, gender in this paper refers to the socially constructed roles that vary according to socio-economic and cultural-political context - masculinities, femininities and social ideas of what makes one a victim or a perpetrator - that gain an especially significant meaning in post-conflict reconstructions. Thus, when writing gender, a broad definition of understanding is to be considered instead of referring simply to 'women'.

\section{Gender and SSR}

Lately, efforts have been made to devote more attention to gender security. Although no clear definition of gender security exists, key policy documents have aimed at integrating gender, SSR and SALW. One of the most prominent examples is the OECD's SSR Handbook (2009), which, together with the Gender and SSR Handbook published by DCAF (the Geneva Centre for Security Sector Reform), has made commitments to incorporate UNSCR 1325 into policy implementation.

Gender aspects are manifested in the EU's Toolkit on Mainstreaming Gender, while organizations such as the OSCE and PeaceWomen have produced materials aimed almost exclusively at policymakers. Others have called attention to the necessity of simultaneously, rather than sequentially, involving SALW control in SSR missions as early as possible. Organizations such as the Small Arms Survey (SAS) and DCAF draw attention to the problematic aspects of SALW control in the Western Balkans, with increased European engagement in the area.

Nevertheless, most organizations have up to this point failed to problematize the intertwined nature of small arms, SSR and gender.The circulation of large quantities of

operate the system in a manner that is more consistent with democratic norms and sound principles of good governance, and thus contributes to a well-functioning security framework." 
doi: 10.14267/cojourn.2019v4n1a4

small arms disable any effort to stabilize the security sector and reach the desired level of community security. Small arms control and the socio-cultural background behind the extremely high levels of illicit weapons possession and use are crucial elements of civilian security and therefore should be given particular stress in reform attempts that can only succeed if gendered aspects of the related challenges are fully taken into account. This article will offer a discussion of the latter in a section on "Gender and SALW." First, however, a brief presentation of the origins and dynamics of SALW circulation in the Western Balkan region follows.

\section{SALW circulation in the post-conflict Western Balkans}

Regional post-conflict instabilities - political, economic and social insecurity, multiethnic conflicts and crises - have had a profound impact on firearms ownership throughout the six Western Balkan entities. The firearms that formerly belonged to Yugoslavia got into the hands of para-military and sub-state military groups during the war, and eventually spread to organized criminal groups following the Dayton Agreements in 1995. As former Yugoslav states - especially Croatia and Bosnia - were effectively cut off from arms supplies in Serbia and in areas inhabited by Serbs, smuggling networks arose and became significant in these areas in providing the parties with weapons.

Even though the wars and open conflicts ended years ago, the illicit possession of small arms remains a challenge for not only the Western Balkan region, but also from a broader geopolitical standpoint as this region is a major source of cross-border illicit firearms trade beyond the Balkans. Thus, the main underlying objective behind international donors' efforts has been to reduce the amount of illegal circulation and control the whole lifecycle of firearms. However, missions carried out by UNDP and several European governments ${ }^{5}$ have failed to meaningfully reduce the circulation and civilian possession of small arms. As of 2017, according to the Small Arms Survey's (SAS) report, the estimated rate of firearms held were 23.8 small arms per 100 residents, with approximately 436,000 firearms in the hands of a population of $1,831,000$ residents in Kosovo (Small Arms Survey, 2018). Survey-based estimates conducted by SAS rely on household surveys, proxies and seizure reports to gather information about the circulation of unregistered, illegally possessed weapons. These numbers are especially

\footnotetext{
${ }^{5}$ For details see SEESAC's South Eastern Europe SALW Monitor (2006).
} 
doi: 10.14267/cojourn.2019v4n1a4

worrying considering that the Small Arms Survey's baseline assessment estimated there to be approximately $330,000-460,000$ civilian small arms in circulation in 2003, overwhelmingly held by the civilian population (Small Arms Survey, 2003).

Trends of small arms ownership and attitudes towards regulation, as well as to security providers are tremendously complex and vary significantly across the rural-urban divide as well as across different ethnic and age-groups. A looming concern has for long been the ownership of guns and the prevalence of criminality, which is deeply connected to gender-related aspects of community security.

\section{Gender and SALW}

As Bozanic (2016) suggests, the character of the proliferation of small arms and violence is deeply gendered in the post-conflict Western Balkans. Small arms and light weapons (SALW) are predominantly owned by men, reinforcing gender norms of hegemonic masculinity and dominance over the victimized role of women. As of 2015, 97 percent of firearms-related incidents have been committed by male perpetrators in Kosovo and other Western Balkan countries, with the same tendency among homicide victims where men also dominate (SEESAC : 15). Women tend to be more supportive of stricter small arms control, but they remain severely underrepresented in decision-making about firearms. Low recognition and the under-prioritization of gendered dimensions dominates the existing SALW policy structure. A common fallacy in tackling gender issues related to small arms is the fragmented, periodic attempts that focus on quantitatively increasing female participation in security bodies and on making a strong effort focused solely on issues of domestic violence. Nevertheless, it is abundantly clear that a gendered approach does not only mean women per se - it also includes critically questioning roles attributed to both men and women in society. A cultural background in which it is almost exclusively men who possess and use arms and where they are equally perpetrators and victims in the context of weapons-related societal dynamics reinforces a set of power relations on a daily basis. It encourages men to act in the framework of "hegemonic masculinities", while women are left in the role of the victim, deprived of the very essence of agency.

There has not been a fully integrated approach to gender in the framework of statebuilding efforts initiated and implemented by donors such as the UN, the US or the EU. In spite of the pervasive nature of the problem, when it comes to small arms in the Balkans, only a few organizations and donors seem to keep in mind the gender aspects of 
doi: 10.14267/cojourn.2019v4n1a4

the problem. This is problematic because the approach to the gender(ed) implications of security in DDR and SSR missions in the Balkans may determine the future sustainability of peace in the region.

\section{SEESAC's role in security sector reform and gender}

To provide a comprehensive analysis about the ongoing processes and structures in the Western Balkans, discussing SEESAC's role and activities is inevitable; SEESAC, the UNDP's South Eastern and Eastern Europe Clearinghouse for the Control of Small Arms and Light Weapons (SEESAC, or 'the Clearinghouse), is one of the main organizations involved in security sector reform and small arms control policymaking in the Western Balkans. The organization's 2014 South East Europe Regional Implementation Plan, titled 'Combating the Proliferation and Impact of Small Arms and Light Weapons', successfully mainstreams gender. The report, combined with the Clearinghouse's other activities on gendered aspects of SALW provides a stable cornerstone for the inclusion of gender into regional SALW policymaking (SEESAC, 2016). Nevertheless, it fails to go beyond general mainstreaming tools, such as women's participation in policymaking, relying on quantitative and measurable factors of gendering policies. The plan's section on gender mainstreaming focuses on tackling domestic and gender-based violence, gendered policymaking and gender awareness.

By embracing this agenda, SEESAC contributes to the understanding of gender as women, of women as victims, and of men as perpetrators. ${ }^{6}$ By a feminist institutionalist understanding, this approach does not critically examine the socio-cultural structures behind the low participation of women in the security sphere and suggests that mechanically increasing the number of female staff and commissioners results in genderbalanced policies. The approach also assumes that by including more women into policymaking processes, these processes will result in gender-sensitive policies and proposals. Understanding the underlying notion that there is no such existing category as 'women' in general, and that femininities are produced on a wide scale of variety and are informed also by various intersections of socio-economic and socio-cultural circumstances, is

\footnotetext{
${ }^{6}$ At this point, it is essential to articulate that by pointing to the aspects that SEESAC's approach lacks by focusing on domestic and gender-based violence in connection to SALW arms, the author of this article does not aim to devaluate and invalidate the vital importance of these notions, which are undeniably crucial and key in terms of gendering small arms control. The central goal of this analysis is rather to illustrate how these goals in themselves are not able to convey transformative change in terms of socio-cultural aspects of gendered small arms.
} 
doi: 10.14267/cojourn.2019v4n1a4

critical. As McLeod (2011) asserts, the focus on the victimized woman subject stems from the reluctancy to include gender in "hard" security qualities The distinction between "hard" and "soft" security measures in terms of gender has been in the center of works discussing international gender mainstreaming policy: women are more frequently involved in operations related to peace and less with the militarized aspects of security. They tend to remain left out of the politico-military processes and decision-making - as a case study of the OSCE demonstrates (Farr, Myrttinen, and Schnabel 2009; EngbergPedersen, Fejerskov, and Cold-Ravnkilde 2020). Thus, numerous critical feminist scholars argue that increasing the number of urban, middle-class women in the decisionmaking processes does not mean that the interests of rural and/or working class women will be comprehended and incorporated into actual policies. This is even more relevant in the case of SALW policy, where gender mainstreaming can reveal hidden mechanisms and insights that would otherwise stay closed from the outsider eye.

A recent initiative has been brought to life as part of the Berlin Process, with the regional coordination of SEESAC, the result of which has been the creation of the Roadmap for a sustainable solution to the illegal possession, misuse and trafficking of small arms light weapons (SALW) and their ammunition in the Western Balkans by 2024 (Roadmap). The initiative has emerged under the auspices of Franco-German cooperation, with the support of the European Union (EU). The Roadmap is the latest step towards the overarching objective of countering the illicit possession and trafficking of small arms in the region. According to the Roadmap, the cooperating partners give special attention to gender-related aspects of SALW, based on a gender analysis that has preceded and been incorporated into the Roadmap. However, the exact incorporation of the gender perspective remains unclear as neither of the seven clearly defined goals of the Roadmap contain objectives with regards to gender. Besides, the key performance indicators, based on which the implementation of the process will be monitored and evaluated do not contain oversight measures on gender mainstreaming.

Nevertheless, even without fully comprehensive support for various angles of gender mainstreaming, SEESAC has and continues to significantly contribute to genderaware policy-making in the Balkans. The organization has a strong focus on advocating for change, producing research that aims to fill the gaps. One of the main areas SEESAC is heavily involved with is gender and SALW policy in South-Eastern Europe and more specifically the Western Balkans. Considerable research has been done by the organization on how to include gender in practical policy-making on firearms (Gender 
doi: 10.14267/cojourn.2019v4n1a4

Aspects of SALW and How to Address Them in Practice, 2018) and on gender and SALW in SEE (2016). A toolkit for policymakers (A Practical Tool for Integrating the Gender Perspective in SALW Legislative And Policy Framework, 2016) and several other works provide thorough and detailed analysis of existing policy frameworks. With their support, grassroot organizations such as Women in Black (a feminist anti-military organization with an extensive network throughout the Western Balkans) have been able to receive support, which contributes to a bottom-up approach to gender security.

\section{Discussion}

An inherent element of SSR missions is still clearly missing from relevant scholarship: most of the available literature underscores features of local ownership and a general understanding of gender mainstreaming, but fails to critically question the institutions, power relations and core political hierarchies that underly each operation. Feminist institutionalism helps to expand the perspective of how post-conflict institutions are not at all gender-neutral and how notions of power in both formal and informal settings need to be elaborated on for successful change in the security and defence sector, peacekeeping and conflict prevention (Ansorg and Haastrup 2018).

Questioning forms and norms of masculinity as well as hidden power dynamics in institutions is essential for identifying key challenges for security sector reform. Based on interviews with SSR practitioners, various scholars report that gender remains in the backseat, not at the center of attention, when it comes to peacebuilding and operating in post-conflict environments. As Gordon, Welch and Roos (2015) illustrate, the reason behind this rationale is the false assumption that "gendering" operations may risk the failure of the entire operation with power relations and hierarchies in flux. Still, the application of gendered norms in areas that are essentially patriarchal bears the danger of undermining the concept of local ownership. This risk is even more acute when it comes to environments that almost fully consist of a male ruling elite in the political driving seat. Therefore, local ownership of the process may be considered to be in conflict with certain notions of bringing about new, gendered security realities. However, as Gordon argues, these realities play an inherent role in post-conflict reconstruction and a gendered lens contributes in ways more meaningful than any approach that came to materialization in the Western Balkans (Gordon 2015).

Each SSR and DDR mission relies on the same theoretical basis, but in successfully achieving the goals of local ownership and embracing the inclusion of 
doi: 10.14267/cojourn.2019v4n1a4

women in decision-making positions the local socio-cultural background plays an inevitably decisive role. The experience of double oppression, closely linked to the intersectionality of ethnicity and gender, creates barriers that are not accounted for in policy-planning and implementation. Besides, broader intersections such as social class and rural-urban antagonisms are considered completely distinct and as issues entirely independent of gender mainstreaming and the transformation of gender roles.

The structural barriers that are posed in terms of female participation in security processes include the extreme masculinity of the security sphere, women's experiences and socio-cultural mechanisms from the war (as those of a marginalized group), their experiences as victims of small arms violence or as agents of the war, as well as a mixture of these all. Critical examination of existing power positions enables a thorough analysis of so far hidden underlying processes, such as rituals and cultural practices as the "carriers" of the structural reinforcement of masculinities (McLeod 2015). Discovering the hidden factors of small arms circulation is only made possible through exploring realities other than the masculine perceptions reflected in current security and SALW processes.

As the case studies in various edited volumes showcase, listening to marginalized voices - voices of women throughout the age-ethnicity nexus or the voices of young men - enables policymaking that realistically builds on the local ownership of processes (Farr, Myrttinen, and Schnabel 2009; Woodward and Duncanson 2017; Engberg-Pedersen, Fejerskov, and Cold-Ravnkilde 2020). Therefore, the perceived paradox between gender and ownership can be resolved: women and a critical, feminist institutionalist, gendered lens do have meaningful and practical things to say about security.

\section{Conclusion}

In the Western Balkans - the case study of this research paper - the post-conflict provision of security, as well as defence and SALW-related policy-making are still marked by the dominance of male decision-makers and practitioners, and gender-blind policies. Security Sector Reform (SSR) is mainly conducted by internationals. They theoretically embraced the importance of women's empowerment in the relevant sectors. In reality, however, predominantly male practitioners are setting the agenda for their male counterparts in an essentially masculinized post-conflict environment. This holds true when it comes to SALW control, an area that has a mixed record of efforts to reflect on its highly gendered nature. As the $20^{\text {th }}$ anniversary of UNSCR 1325 approaches, it would be best for 
doi: 10.14267/cojourn.2019v4n1a4

policymakers and international SSR donors to keep in mind the original aim of the resolution: embracing the role of gender and reflecting not only on women's role but also on power relations in a post-conflict society. It would be similarly important to investigate the intersection of hierarchies that reinforce societal marginalization on an institutional, automatic and daily basis, and tackle these existing hierarchies in a manner that effectively responds to the challenges that manifest themselves in a certain domain. With regards to small arms control - an inherent part of SSR missions - much has been learned but even more is yet to be uncovered. It is time policymakers focused not only quantitatively on women's inclusion into SALW control, but on questioning the types of masculinities, femininities and other gendered identities that prevent meaningful societal change.

\section{References}

Ansorg, Nadine, and Eleanor Gordon. 2019. "Co-Operation, Contestation and Complexity in Post-Conflict Security Sector Reform." Journal of Intervention and Statebuilding 13 (1): 2-24. https://doi.org/10.1080/17502977.2018.1516392.

Ansorg, Nadine, and Toni Haastrup. 2018. “Gender and the EU's Support for Security Sector Reform in Fragile Contexts: Gender \& the EU's Support to SSR.” JCMS: Journal of Common Market Studies 56 (5): 1127-43. https://doi.org/10.1111/jcms. 12716.

Baliqi, Bekim. 2018. "Contested War Remembrance and Ethnopolitical Identities in Kosovo." Nationalities $\quad$ Papers $46 \quad$ (3): 471-83. https://doi.org/10.1080/00905992.2017.1375906.

Carapic, Jovana. 2014. "Handgun Ownership and Armed Violence in the Western Balkans." Small Arms Survey.

Dursun-Ozkanca, Oya, and Katy Crossley-Frolick. 2012. "Security Sector Reform in Kosovo: The Complex Division of Labor between the EU and Other Multilateral Institutions in Building Kosovo's Police Force.” European Security 21 (2): 23656. https://doi.org/10.1080/09662839.2012.665886.

Ellerby, Kara. 2013. “(En)Gendered Security? The Complexities of Women's Inclusion in Peace Processes." International Interactions 39 (4): 435-60. https://doi.org/10.1080/03050629.2013.805130. 
doi: 10.14267/cojourn.2019v4n1a4

Engberg-Pedersen, Lars, Adam Moe Fejerskov, and Signe Marie Cold-Ravnkilde. 2020. Rethinking Gender Equality in Global Governance: The Delusion of Norm Diffusion. https://doi.org/10.1007/978-3-030-15512-4.

Farquet, Romaine. 2018. "Nation-Building, Masculinity and Entrepreneurship: Memories of the 'Liberation of Kosovo' in Switzerland." Ethnic and Racial Studies 41 (2): 362-80. https://doi.org/10.1080/01419870.2017.1318214.

Farr, Vanessa, Henri Myrttinen, and Albrecht Schnabel, eds. 2009. Sexed Pistols: The Gendered Impacts of Small Arms and Light Weapons. Tokyo New York: United Nations University Press.

Gajić, Sonja Stojanović. 2017. "Capacity Building for Security Sector Reform in Kosovo," no. 02: 41.

Gibbings, Sheri Lynn. 2011. "No Angry Women at the United Nations: Political Dreams and the Cultural Politics of United Nations Security Council Resolution 1325.” International Feminist Journal of Politics 13 (4): 522-38. https://doi.org/10.1080/14616742.2011.611660.

Gordon, Eleanor. 2014. "Security Sector Reform, Statebuilding and Local Ownership: Securing the State or Its People?" Journal of Intervention and Statebuilding 8 (23): 126-48. https://doi.org/10.1080/17502977.2014.930219.

2015. "Security Sector Reform and the Paradoxical Tension between Local Ownership and Gender Equality." Stability: International Journal of Security \& Development 4 (1): 53. https://doi.org/10.5334/sta.gj.

— 2019. "Gender and Defence Sector Reform: Problematising the Place of Women in Conflict-Affected Environments." Journal of Intervention and Statebuilding 13 (1): 75-94. https://doi.org/10.1080/17502977.2018.1516389.

Greiçevci, Labinot. 2011. "EU Actorness in International Affairs: The Case of EULEX Mission in Kosovo." Perspectives on European Politics and Society 12 (3): 283303. https://doi.org/10.1080/15705854.2011.596307.

Heinemann-Grüder, Andreas, and Igor Grebenschikov. 2006. "Security Governance by Internationals: The Case of Kosovo.” International Peacekeeping 13 (1): 43-59. https://doi.org/10.1080/13533310500424744.

Holvikivi, Aiko. 2015. "What Role for the Security Sector? An SSR Approach to Implementing the Women, Peace and Security Agenda." Connections: The Quarterly Journal 14 (3): 31-44. https://doi.org/10.11610/Connections.14.3.03. 
doi: 10.14267/cojourn.2019v4n1a4

Huber, Laura K., and Natalie F. Hudson. 2019. "Deepening the Conversation: Feminism, International Policing and the WPS Agenda.” International Peacekeeping, June, 1-26. https://doi.org/10.1080/13533312.2019.1632706.

Jenichen, Anne, Jutta Joachim, and Andrea Schneiker. 2018. “'Gendering' European Security: Policy Changes, Reform Coalitions and Opposition in the OSCE." European $\quad$ Security $\quad 27 \quad$ (1): $\quad 1-19$. https://doi.org/10.1080/09662839.2018.1433660.

Krause, Jana, Werner Krause, and Piia Bränfors. 2018. "Women's Participation in Peace Negotiations and the Durability of Peace." International Interactions 44 (6): 9851016. https://doi.org/10.1080/03050629.2018.1492386.

MacKenzie, Megan. 2009. "Securitization and Desecuritization: Female Soldiers and the Reconstruction of Women in Post-Conflict Sierra Leone.” Security Studies 18 (2): 241-61. https://doi.org/10.1080/09636410902900061.

McLeod, Laura. 2011. "Configurations of Post-Conflict: Impacts of Representations of Conflict and Post-Conflict upon the (Political) Translations of Gender Security within UNSCR 1325.” International Feminist Journal of Politics 13 (4): 594-611. https://doi.org/10.1080/14616742.2011.611664.

. 2015. "A Feminist Approach to Hybridity: Understanding Local and International Interactions in Producing Post-Conflict Gender Security.” Journal of Intervention and Statebuilding $9 \quad$ (1): 48-69. https://doi.org/10.1080/17502977.2014.980112.

Mobekk, Eirin. 2010. “Gender, Women and Security Sector Reform.” International Peacekeeping 17 (2): 278-91. https://doi.org/10.1080/13533311003625142.

Munn, Jamie. 2008. "The Hegemonic Male and Kosovar Nationalism, 2000-2005." Men and Masculinities $10 \quad 440-56$. https://doi.org/10.1177/1097184X07306744.

Myrttinen, Henri, Lana Khattab, and Jana Naujoks. 2017. "Re-Thinking Hegemonic Masculinities in Conflict-Affected Contexts." Critical Military Studies 3 (2): 10319. https://doi.org/10.1080/23337486.2016.1262658.

Organisation for Economic Co-operation and Development. 2008. The OECD DAC Handbook on Security System Reform. Paris: OECD Publishing.

Porter, Elisabeth. 2003. "Women, Political Decision-Making, and Peace-Building." Global Change, Peace \& Security $15 \quad$ (3): 245-62. https://doi.org/10.1080/0951274032000124965. 
doi: 10.14267/cojourn.2019v4n1a4

Pupavac, Vanessa. 2010. "Weaving Postwar Reconstruction in Bosnia? The Attractions and Limitations of NGO Gender Development Approaches." Journal of Intervention and Statebuilding $4 \quad$ (4): 475-93. https://doi.org/10.1080/17502977.2010.489771.

SEESAC, 2016. "Gender and SALW in South East Europe. Main Concerns and Policy Response."

Shepherd, Laura J. 2011. "Sex, Security and Superhero(in)Es: From 1325 to 1820 and Beyond." International Feminist Journal of Politics 13 (4): 504-21. https://doi.org/10.1080/14616742.2011.611659.

Simangan, Dahlia. 2018. "Domino Effect of Negative Hybrid Peace in Kosovo's Peacebuilding." Journal of Intervention and Statebuilding 12 (1): 120-41. https://doi.org/10.1080/17502977.2018.1423772.

Skendaj, Elton, Klime Babunski, Zdenka Milivojevic, and Seb Bytyçi. 2019. "Local Ownership and International Oversight: Police Reform in Post-Yugoslav States.” Journal of Intervention and Statebuilding, May, 1-24. https://doi.org/10.1080/17502977.2018.1559581.

Small Arms Survey, 2003. "Kosovo and the Gun: A Baseline Assessment of Small Arms and Light Weapons in Kosovo."

_. 2018. "Estimating Global Civilian-Held Firearms Numbers". Briefing Paper.

"South Eastern Europe SALW Monitor 2006." 2006. South Eastern and Eastern Europe Clearinghouse for the Control of Small Arms and Light Weapons (SEESAC).

Triantafyllou, Giorgos. 2018. "Statehood without an Army: The Question of the Kosovo Armed Force." Southeast European and Black Sea Studies 18 (2): 261-79. https://doi.org/10.1080/14683857.2018.1474578.

Willett, Susan. 2010. "Introduction: Security Council Resolution 1325: Assessing the Impact on Women, Peace and Security." International Peacekeeping 17 (2): 14258. https://doi.org/10.1080/13533311003625043.

Woodward, Rachel, and Claire Duncanson, eds. 2017. The Palgrave International Handbook of Gender and the Military. London: Palgrave Macmillan UK. https://doi.org/10.1057/978-1-137-51677-0. 